\title{
VIKRAMĀDITYA AND KĀLIDĀSA
}

Dr. A. R. Hoernle's most interesting article on Vikramāditya in the last number of the Journal revives and supports very strongly a theory of the date of Kālidāsa which I had thought had now been definitely abandoned. ${ }^{1}$ I should wish, therefore, to point out certain objections to this theory; they do not touch upon the main principles of Dr. Hoernle's article, and even if they are considered of weight they merely rob the history of Yaśodharman of some minor details. I have the less hesitation in urging the objections, because they are not based on any theory of my own, but are merely matters regarded as conclusive by Kielhorn and Bühler, and because I am anxious that we should as far as possible maintain the chronological bases won for us by their discoveries.

In the first place, Dr. Hoernle appears to underestimate the force of the evidence for the posteriority of Vatsabhatți, author of the Mandasor Inscription of A.D. 473, to Kālidāsa. That v. 31 of that inscription is an imitation of the Rtusamharra, v, 2 and 3, is not only believed by Kielhorn, ${ }^{2}$ but also by Biihler, ${ }^{3}$ and on such a point their joint authority is almost decisive. But Bühler,4 whose work on this point Dr. Hoernle curiously seems to ignore, adduces even a stronger parallel: he points out that vv. 10 and 11 of the inscription imitate clumsily the Meghaduta, v. 65. It is worth while comparing the two passages--

${ }^{1}$ Cf. Vincent Smith, Early History of India ${ }^{2}$, p. 288, n. ; Macdonell, Sanskrit Literature, p. 321 ; with Henry, Les Litteratures de l'Inde, p. 215 ; Oldenberg, Die Literatur des alten Indien, p. 215; Duff, Chronology of India, p. 47 ; my notes, JRAS., 1901, p. $579 ; 1908$, p. $575 ; 1909$, p. 146.

2 Gött. Nach., 1890, pp. 251 seq.

3 Die indischen Inschriften, p. 71, and independently, pp. 24, 25, he compares vv. 33-5 with Rtusamhara, v, 3 and 9. I have no doubt that the Rtusamhära is Kālidāsa's work.

${ }^{4}$ Op. cit., pp. 18 seq. It adds very materially to the argument, especially as some writers still doubt the authenticity of the Rtusamhara (cf. Lévi, Theadtre indien, ii, 34; Henry, p. 217, n. 1 ; Oldenberg, p. 217, n. 1), which Dr. Hoernle does not do. 
Meghadūta, v. 65 :

vidyutvantam lalitavanitāh sendracāpam sacitrā

samgītāya prahatamurajāh snigdhagambhīraghosam |

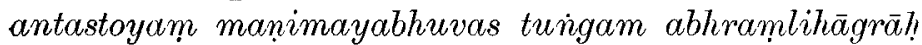

prōsāāas tvām tulayitum yatra tair tair visésaih $\|$

Mandasor Inscription, vv. 10, 11 :

calatpatākāny abalāsunāthāny

atyarthaśullāny adliikonnatāni

tadillatācitrasitābhralk ūta-

tulyopamānāni grhāni yatra \|

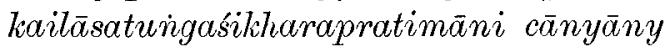

$\bar{\alpha} b h \bar{\alpha} n t i$ dīrghavalabhīni savedikāni |

gāndharvaśabdamukharāni nivistacitra-

karmāni lolakadalīvanaśobhitāni

I feel little doubt that one must accept Buhler's view that the inscription is an attempt to outdo the poem. The ideas here are not by any means commonplace, and Liebich's dictum ${ }^{1}$ that identity of phrase is needed, even if generally tenable, would be out of place.

Further, Buihler ${ }^{2}$ points out that, like Kälidāsa, Vatsabhattti is fond of the word subhaga, and that prasadda$m \bar{a} l \bar{a} b h i \hbar$ in v. 12 is paralleled by prasādamāa $\bar{a} s u$ in Kumārasambhava, vii, 56 . The fact that this occurs in v. 12 is significant. The poet who admits (v. 44) that he wrote prayatnena apparently is anxious to show chiefly that he used the best models. Moreover, he plays ${ }^{3}$ on the word Bandhuvarman exactly as does Kālidāsa with the names of the Raghuides at the beginning of Raghuvamsia, $\mathrm{xviii}$. This is a substantial body of evidence.

That Kālidāsa borrowed from Vatsabhatṭi is unthinkable in view of the passages mentioned above; that Vatsabhatti

1 Cited by Hoernle, JRAS., 1909, p. 111.

2 Op. cit., p. 71.

${ }^{3}$ v. 26 : bandhupriyo bandhur iva prajānām | bandhvartihartā nrpa. bandhuvarma $\mid$ For bandhupriyo, cf. Nala, i, 2, aksapriyah, no doubt in both cases active. Cf. Vārtt. 2 on Pānini, ii, 2, 35. 
is identical with the author of the Bhattikāvya is a most unfortunate suggestion of Mr. Mazumdar's, ${ }^{1}$ which Dr. Hoernle yet seems to deem possible. But if the author of that Kāvya is "an equally great poet" with Kālidāsa, then he is certainly not Vatsabhațți, who has, as Buihler ${ }^{2}$ convincingly and in detail shows, no claim to be a poet of anything like the first order, but is a mere diligent versifier of a petty court. Such a valuation of the Bhattikāvya seems to me extravagant, though I readily admit that the author stands in quite a different class from Vatsabhatți.

In the second place, Dr. Hoernle says that " in the Meghaduta of Kālidāsa there is a well-known verse which names Diñnāga as his adversary ", 3 and Dinnāga he ascribes to about A.D. 520.4 I do not propose to comment on the date of Dinnäga. There are difficulties about his relationship to Vasubandhu ${ }^{5}$ and Vasubandhu's own date, ${ }^{6}$ which there are no adequate materials to settle. But the most important fact is that we have only Mallinātha's word that Dinnāga is referred to at all. The Yakșa, addressing the cloud, says :

adreh śrngam harati pavanah kimsvid ity unmukhêbhih

drstotsāhas cakitacakitam mugdhasiddhāinganäbhih!

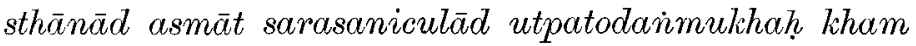

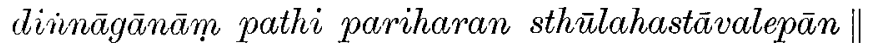

On this verse Mallinätha gives as an arthāntaranyāsa

1 JRAS., 1904, pp. 396 seq. The priority of Bhațti to Bhäravi and Dandin is, of course, no evidence for identity with Vatsabhatti, and the omission of the end of the Rämãyana proves nothing, as it can hardly be seriously argued that the last book of that Epic is nearly as late as A.D. 473. The description of Dharasena as narendra is in favour of Dharasena I having been Bhatți's patron, and if so, he dates before A.D. 520 (cf. Hoermle, p. 13i ; Bombay Gazetteer, i, 1, 88). The Bhartṛhari ascription is hopeless (cf. my App. to Bodl. Catal., p. 32 and reff.).

2 Op. cit., pp. $26-9$.

4 Ibid., p. 139.

3 JRAS., 1909, p. 110.

5 Búhler, op. cit., p. 79, n. 2.

${ }^{6}$ Cf. Macdonell, op. cit., p. 325 ; Takakusu, JRAS., 1905 (not 1906), p. 42, n. 1 . 
a reference to a friend of Kālidāsa's, a great poet, Nicula, and an enemy, Dinnāga, whose name is, however, put in the plural päjāyam. Soberly, what value has the late scholium, which has in itself no evidence of antiquity, and which does not even designate Dinnāga as anything but a pratipakşa of Kälidāsa? Why should Dinnāga, a Buddhist logician, have troubled Kälidāsa? I consider the tradition as utterly worthless as the references seen by the scholiasts in Aristophanes or Horace ${ }^{1}$ to contemporary writers and men. Curious that a mahăkavi like Nicula should have vanished so completely from knowledge. But in any case Dr. Hoernle should have reminded us that the tradition has been disbelieved or doubted by very high authority, ${ }^{2}$ and that the arthantaranya $\bar{a} s a$, if real, would be a very poor one; quite incredible in Kālidāsa, who uses dirna ăga as a common noun again in the Kumāarasambhava.

In the third place, Dr. Hoernle seems to me to lay quite undue stress on the similarity of the digvijaya described in the Raghuvamśa, iv, 26-85, with that of Yaśodharman according to the Mandasor Inscription of about A.D. 533. ${ }^{3}$ But this similarity seems merely apparent. The inscription mentions only the Himälaya, the Western Ocean, the Lauhitya, the Mahendra, and the Gangā (apparently here the Sindhu affluent of the Vitasta $\left.\bar{a}^{4}\right)$. It commences with the Lauhitya. The poem does not even end with the Lauhitya, but with Kāmarūpa, and the Lauhitya only appears in v. 81, nor is any stress laid on it as in the inscription. The Gangā appears as the ordinary Ganges ${ }^{5}$

1 Cf. Palmer, Horace's Satires, pp. xiv seq.

${ }^{2}$ Buihler, op. cit., p. 79 ; Macdonell, op. cit., p. 324 ; Weber, ZDMG., xxvi, 726 seq. ; Bohtlingk and Roth, in the St. Petersburg Dictionary, merely cite Mallinätha, and do not endorse his view; Monier-Williams' Dict. ${ }^{2}$ cites no authority for either sense save the Mahäbhärata, no doubt by an error.

3 See Fleet, Gupta Inscriptions, pp. $146 \mathrm{seq}$.

${ }^{+}$Hoernle, p. 110, n. 1 ; Cakravarti, JRAS., 1904, p. 159.

5 In Raghuvamsa, iv, 67, the Sindhu appears but only as a v.l. ; cf. Cakravarti, loc. cit. 
in the poem, and the Western Ocean must occur in every digvijaya. Dr. Hoernle's more substantial point is that Kasmir is referred to in the digvijaya of the Raghuvamśa, and that no Gupta ever held Kaśmir, while Yaśodharman did. It is impossible to say whether Yasodharman ever held Kaśmir ; his boast is so vaguely expressed ( $\bar{\alpha}$ Gangāslistasānos tukharaśikharinah) that one cannot judge what it exactly means. Nor, indeed, is there any decisive evidence against Candragupta II having conquered or claimed to conquer Kasmirr, if we choose to read history into poetry, and that, too, poetry which makes no claim itself to be contemporary history, and which if it did base itself on contemporary history would be entitled to a large degree of licence, such as was taken by Virgil and Propertius in their epicedia for Marcellus. ${ }^{1}$

But, in truth, as Biihler ${ }^{2}$ pointed out, the poem shows in every line that Raghu's march is a poetical one, not a real one. Just as Somadeva ${ }^{3}$ copies Kālidāsa in an account presumably meant to be at least as historical as that of Raghu's conquests, so Kālidāsa followed the Epics, the Purānas, and other Kāvya writers. He makes Raghu conquer Pārasīkas, Hūṇas, Kāmbojas, Yavanas, et hoc genus omne; he simply defeats for him all warlike nations,

1 Since the abore was written, there has appeared Dr. Bloch's note on "Die Zeit Kālidāsa's" in ZDMG., lxii, 671-6. He finds in the same digvijaya a reflection of the glories of Samudragupta, and in the completeness of the description of the southern conquests of the king a parallel to lines 19 and 20 of the Allahabad Inscription. He also calls attention to the analogy of Räma's history with that of the Gupta family, a union of east and. west, and finds in iv, 20, ikşuchāyanişādinyas tasya goptur gunodayam ākumārakathodyhātam śāligopyo jagur yaśah, references to Candragupta and Kumāragupta. So far as the digvijayo is concerned, I am as little convinced by Dr. Bloch as by Dr. Hoernle, but certainly the note of the former shows how little weight can be placed on the suggestion of the latter. The reference to Kumāragupta and the Guptas generally is more convincing, and Dr. Bloch reminds us of the connection of Candragupta II with Virasena, a Kautsa, with which may be compared the hermitage of Kautsa in Raghuramsa, v.

${ }^{2}$ Op. cit., p. 82.

3 See Hoernle, p. 121, n. 2. 
and Dr. Hoernle ${ }^{1}$ is surely not well advised in seeking from this a victory of Yaśodharman over the Persians. Vàkpati in the Gaüdavaho brings his hero to the Yakșa princes $^{2}$ and against the Persians (then non-existent) in the same style as Kālidāsa treats of Raghu's performances; and to find a sober account of any historic event is hopeless. In a far more critical age Horace and Virgil allow themselves to ascribe to their sovereign conquests over Arabians and Parthians which existed only in the imaginations of the Imperial Court, and the later emperors like Domitian ${ }^{3}$ made still more remarkable claims.

But, indeed, if we will press Kālidāsa he yields here an unfavourable result for Dr. Hoernle. For he begins the digvijaya by a very significant line, iv, 26 :

sa guptamūlapratyantah śuddhapārṣnir ayānvitah |

șadvidham balam àdāya pratasthe digjigişay $\bar{\alpha} \|$

It may be a mere coincidence, but the word gupta standing here can well be significant, and that in the proper mode of significance in poetry, ${ }^{4}$ when the reference is a mere hint, vocal to the intelligent, but not obtruding reality on art. In the same connection, in iv, 68, vyalitavikramam reminds us with equal felicity of Vikramāditya, one of the undoubted titles ${ }^{5}$ of the king, Candragupta II; and vikrama recurs in vv. 42 and 59 , a fact probably not without significance.

Or again, what evidence is there for conquests over Pạndyas, Colas, Kerala, Yavana? Dr. Hoernle adorns the history of Yaśodharman with victories over the first three, but why not over the last? It is true that Yavanas

I p. 133. Dr. Bloch, p. 675, finds a proof of the existence of Western peoples in India in Samudragupta's time, and compares the Sähi, Sāhānuṣāhi, Śaka, and Muruṇda of line 23 of the Allahabad Inscription. But this is quite unconvincing.

${ }^{2}$ Cf. Hoernle, p. 106 ; Bühler, p. $82 . \quad{ }^{3}$ Cf. Merivale, Hist., vii, 344.

4 Cf. Grierson, JRAS., 1903, p. 363, and see Jebb, EEdipus Coloneus, p. xlii. Bloch, p. 673, has some very pertinent remarks on this point.

${ }^{5}$ Hoernle, JRAS., 1909, p. 103 ; Vincent Smith, Early History of India ${ }^{2}$, pp. 275 seq. 
would be hard to find, but logically they might as well be deemed real as the others. Surely these serious discrepancies of the tradition leave much room for doubt as to Yaśodharman's round of conquests serving Kālidāsa for a model. Cakravarti's ${ }^{1}$ attempt to find in Skandagupta's digvijaya a model is doubtless wrong, but it is just as plausible as the new effort. The date of Varāhamihira, moreover, cannot be safely placed at A.D. 504-81 (? 87). There is ground for believing that he wrote ${ }^{2}$ in A.D. 504. But apart from that fact, the idea that his date is any help in fixing Kälidāsa's as his contemporary rests merely on the utterly worthless and late Navaratna tradition, which should not be revived, and, in fact, Kālidāsa shows no trace of influence of Varāhamihira, or even of Āryabhaț. All the astronomy he knows he could easily have learnt, as he no doubt did learn it, from the older Siddhäntas. ${ }^{3}$

I hold, therefore, that the Kālidāsa evidence is quite against the theory of Yaśodharman Vikramāditya and in favour of that of Candragupta II, who, as far as I can judge, is also pointed to by the other literary evidence. ${ }^{4}$

\section{A. Berriedale Keith.}

1 JRAS., 1903, pp. 183 seq. ; 1905, pp. 158 seq., where he quotes Professor Pathak as concurring, and recalling his old view which is accepted as correct by Hoernle (p. 109).

2 Cf. Thibaut, Astronomie, p. 56 ; S. B. Dikshit, Ind. Ant., xix, 45 seq., 133 seq. ; Bühler, op. cit., p. 4.

3 Bühler, pp. 80, 81.

4 That from Subandhu and Candragomin is certainly ambiguous. A reference to a Vikramāditya in the former points to Skandagupta who bore the title (Hoernle, p. 102), and on whose death the empire did go to ruins (ibid., p. 14l), rather than to Yasodharman, who does not take the title in the inscriptions which certainly refer to him. That in Candragomin must remain vague until Jarta is explained. Yasodharman may have been a Jāṭ, whoever the Jāṭs were, but that is a mere possibility and nothing more. I suspect that he was not so great a man as his records would make out, and that Bālāditya had some claim to have resisted the Huns. Cf. also Fleet, JRAS., 1904, pp. 164-7. 